\title{
Ultimate Strength of Ships and Offshore Structures
}

\section{Carlos Guedes Soares ${ }^{1}$}

Published online: 15 January 2021

(C) The Author(s) 2021

The assessment of the ultimate strength of floating structures is an essential step in their design process and thus it is included as one of the checks in the Rules of Classification Societies. Several years ago, the Rule requirement was based on the section modulus associated with the yield condition, a situation that has been shown to be clearly conservative by an amount that would depend on the geometry of the section. The development of methods to quantify the ultimate strength, including the ability of numerical methods to deal with those predictions in a relatively cost-efficient manner, led to proposals that the ultimate strength should be used as the reference value expressing the strength of the ship hull structure (Guedes Soares et al. 1996), which was adopted 10 years later by the Classification Societies in their Common Structural Rules (CSR 2006; IACS 2014). Indeed, the present status of design relies on ultimate strength assessment and on nonlinear wave induced loads, which have been covered in and earlier special issue (Guedes Soares and Duan 2018).

Different numerical methods have been developed for ultimate strength assessment and new simplified approaches are continuously being proposed, as simplified methods dully calibrated and validated are always welcome as substitutes of very heavy computational approaches. The Common Structural Rules, prescribe simplified methods such as the one of Smith (1977) for the assessment of hull girder collapse and of Gordo and Guedes Soares (1993) for the ultimate strength of stiffened panels.

Carlos Guedes Soares

c.guedes.soares@centec.tecnico.ulisboa.pt

1 Centre for Marine Technology and Ocean Engineering (CENTEC), Instituto Superior Técnico, Universidade de Lisboa, 1409-001 Lisboa, Portugal
The ultimate strength assessment, which was primarily concerned with intact structures, have been extended to damaged structures, including both the prediction of damage induced in accidental situations as the residual strength of damaged structures. Again, it has been the improved capabilities of numerical methods that allowed the study of the complicated geometries of damaged structures that allowed the design work to rely on this type of predictions.

This special issue covers various of these aspects, including papers of review nature with others presenting new research results. The paper by Tekgoz et al. (2020) is a typical review paper that covers the area of the ultimate strength of ageing and damaged ship structures, dealing extensively with numerical, analytical and experimental work on plates, stiffened panels and hull girders that have suffered aging due for example to corrosion and fatigue or damage due for example to minor collisions.

Liu et al. (2020) concentrates on aluminium structures and at the same time as it presents a good review of the work done on ultimate strength of plates and stiffened panels in aluminium, it also includes a research contribution using finite element analyses to study the influence of manufacturing technology on the ultimate compressive strength of aluminiumalloy stiffened panels. As an important problem in aluminium structures is the heat-affected zone associated with welding, the study compares the performance of these panels with extruded ones, which are being used in progressively more applications.

Barsotti et al. (2020) present an overview of recent industrial developments of marine composites limit states assessments and design approaches, focusing on pleasure crafts and yachts as well as navy ships. Inter-ply and intra-ply failure modes are discussed and the corresponding limit states are presented. The main factors influencing marine composite robustness were found to be three-dimensional aspects in failure 
modes and manufacturing methods as well as fire resistance and joining techniques.

Romanoff et al. (2020) deals with a very special type of problem somewhat associated with cruise ships, in which developments of laser-welded thin-walled steel plates have been made in order to keep light weight at the same time avoiding the weld induced distortions induced by conventional arc welding. This type of structural elements have found application in other vessels and the authors review work that has been done in collision simulations based on finite element analysis of this type of structures.

Wahab et al. (2020) present a different type of problem, which is related with fixed offshore jacket platforms that have been used for many years and are subjected to the problems of planning appropriately their maintenance and eventually develop studies of life extension. The design limit state of these platforms is generally the ultimate strength and thus the paper deals with the problems that degrade the strength of these structures, discussing how a good maintenance plan can maintain the structural strength for longer periods.

The other papers in this issue deal with more specific problems, presenting research results. A first group deals with the buckling strength of shell structures mainly used in subsea applications, while the other papers deal with stiffened panels and with ship hull girders.

Cho et al. (2020) deal with steel-welded hemispheres under external hydrostatic pressure, Zhang et al. (2020) with the buckling of multiple intersecting spherical shells under uniform external pressure and Al-Hamati et al. (2020) study the buckling properties of a subsea function chamber for oil and gas processing in deep-waters.

Lee and Paik (2020) study the ultimate compressive strength computational modelling for stiffened plate panels with non-uniform thickness, a situation that occurs when there is the need to have a transition between plates with different thicknesses.

The rest of the papers deal with the hull girder. Nouri and Khedmati (2020) and Vu and Dong (2020) study the ultimate strength of hull girders deteriorated with different types of corrosion, while Xu and Guedes Soares (2020) study the influence of collision damage on the ultimate strength of hull girders. They consider a box girder representing the parallel middle body of tankers and similar vessels and they validate their finite element model against experiments, before analysing the effect of an impact on different locations, assessing afterwards the residual strength of the damaged structure.

Primorac et al. (2020) continue with the topic of damaged ship hulls by collision or grounding and they analyse the problem of conducting a structural reliability assessment of these damaged ship hulls adopting the procedures recommended in IMO (2006), and they discuss the various limitations of the presently recommended approach.

This set of papers present a good overview of current problems related with the strength assessment of ship and offshore structures, with a certain emphasis on damaged structures, as this type of topic has attracted the attention of several researches in the recent past, and these are in general more complicated problems than dealing with undamaged structures. We hope that this collection of papers will contribute to an overview of this general topic, which can be of interest to readers.

Open Access This article is licensed under a Creative Commons Attribution 4.0 International License, which permits use, sharing, adaptation, distribution and reproduction in any medium or format, as long as you give appropriate credit to the original author(s) and the source, provide a link to the Creative Commons licence, and indicate if changes were made. The images or other third party material in this article are included in the article's Creative Commons licence, unless indicated otherwise in a credit line to the material. If material is not included in the article's Creative Commons licence and your intended use is not permitted by statutory regulation or exceeds the permitted use, you will need to obtain permission directly from the copyright holder. To view a copy of this licence, visit http://creativecommons.org/licenses/by/4.0/.

\section{References}

Al-Hamati AA, Duan M, An C, Guedes Soares C, Estefen S (2020) Buckling properties of SFC for oil /gas processing in deep-waters. J Mar Sci Appl 19(4) 642-657

Barsotti B, Gaiotti M, Rizzo CM (2020) Recent Industrial Developments of Marine Composites Limit States and Design Approaches on Strength. J Mar Sci Appl 19(4) 553-566

Cho S-R, Muttaqie T, Lee SH, Paek J, Sohn JM (2020) Ultimate Strength Assessment of Steel-Welded Hemispheres Under External Hydrostatic Pressure. J Mar Sci Appl 19(4) 615-633

CSR (2006) ABS, DNV, LLOYD'S REGISTER. Common Structural Rules for Double Hull Oil Tankers

Gordo JM and Guedes Soares C (1993) Approximate Load Shortening Curves for Stiffened Plates under Uniaxial Compression. Faulkner D, Cowling MJ \& Incecik A, (Eds.). Integrity of Offshore Structures, 5, Proc 5th International Symposium on Integrity of Offshore Structures. Univ Glasgow, 17-18 June: EMAS;189-211

Guedes Soares C, Duan WY (2018) Wave Loads on Ships and Offshore Structures. J Mar Sci Appl 17(3):281-283

Guedes Soares C, Dogliani M, Ostergaard C, Parmentier G, Pedersen PT (1996) Reliability Based Ship Structural Design. Trans Soc Naval Architects Marine Eng (SNAME) 104:357-389

IACS (2014) Common structural rules for bulk carriers and oil tankers. Societies, International Association of Classification

IMO (2006) Maritime Safety Committee MSC 81/INF.6. Goal-based new ship construction standards - linkage between FSA and GBS International Maritime Organisation

Lee HH, Paik JK (2020) Ultimate Compressive Strength Computational Modelling for Stiffened Plate Panels with Non-Uniform Thickness. J Mar Sci Appl 19(4) 658-673

Liu B, Doan VT, Garbatov Y, Wu WG, Guedes Soares C (2020) Study on Ultimate Compressive Strength of Aluminium-Alloy Plates and Stiffened Panels. J Mar Sci Appl 19(4) 534-552 
Nouri Z, Khedmati MR (2020) Progressive Collapse Analysis of a FPSO Vessel Hull Girder under Vertical Bending considering Different Corrosion Models. J Mar Sci Appl 19(4) 674-692

Primorac BB, Parunov J, Guedes Soares C (2020) Structural Reliability Analysis of Ship Hulls Accounting for Collision or Grounding Damage. J Mar Sci Appl 19(4) 717-733

Romanoff J, Körgesaar M, Remes H (2020) Emerging Challenges for Numerical Simulations of Quasi-Static Collision Experiments on Laser-Welded Thin-Walled Steel Structures. J Mar Sci Appl 19(4) 567-583

Smith CS (1977) Influence of Local Compressive Failure on Ultimate Longitudinal Strength of a Ship's Hull, Proc. Conf. on Practical Design of Ships and Mobile Units (PRADS), Tokyo, 73-79
Tekgoz M, Garbatov Y, Guedes Soares C (2020) Review of Ultimate Strength Assessment of Ageing and Damaged Ship Structures. J Mar Sci Appl 19(4) 512-533

Vu VT, Dong DT (2020) Hull Girder Ultimate Strength Assessment Considering Local Corrosion. J Mar Sci Appl 19(4) 693-704

Wahab MMA, Kurian VJ, Liew MS, Kim DK (2020) Condition Assessment Techniques for Aged Fixed-type Offshore Platforms considering Decommissioning: A Historical Review. J Mar Sci Appl 19(4) 584-614

$\mathrm{Xu}$ W, Guedes Soares C (2020) Numerical Investigation on the Ultimate Strength of Box Beams with Impact Damage. J Mar Sci Appl 19(4) 705-716

Zhang J, Li SQ, Cui WC, Xiang K, Wang F, Tang WX (2020) Buckling of Multiple Intersecting Spherical Shells Under Uniform External Pressure. J Mar Sci Appl 19(4) 634-641 